\title{
情動記憶の消去過程に関与する脳内メカニズム
}

筑波大学大学院人間総合科学研究科

山田一夫・一谷 幸男

\section{Neural mechanisms underlying extinction of emotional memory}

\author{
Kazuo YAMADA \& Yukio ICHITANI \\ Institute of Psychology and Behavioral Neuroscience, \\ University of Tsukuba \\ Tsukuba 305-8577, Japan
}

Development of pharmacological manipulations that facilitate extinction of emotional memory may lead to improvement in treatment effectiveness for anxiety disorders such as PTSD, and drug dependency. The first part of this paper explains Pavlovian fear conditioning and conditioned place preference which are typically used to measure aversive and euphoric emotional memories respectively. The next part explains behavioral mechanisms of the extinction of conditioned fear responses and reviews important findings on the role of the amygdala, hippocampus and medial prefrontal cortex in the extinction of emotional memory. The final part reviews the latest studies on involvement of brain glutamatergic NMDA receptors in the extinction. In conclusion, partial NMDA receptor agonist, D-cycloserine, may have potential clinical benefits. (Japanese Journal of Physiological Psychology and Psychophysiology, 26(1) : 27-39, 2008.)

Key words : emotional memory, extinction, fear conditioning, conditioned place preference, NMDA receptor, amygdala, hippocampus, medial prefrontal cortex

【要 約】情動記憶の消去を薬理学的に促進することは, PTSD や不安症, そして薬物依存の治療に有用である。 本稿では，まずラットの情動記憶の測定方法として，恐怖条件づけと条件性場所選好について概説し，それらの 条件性反応の消去メカニズムと, 扁桃体, 海馬, 内側前頭前野との関わりについての最近の研究知見を概観した。 また消去におけるグルタミン酸受容体の役割についての知見も紹介し, PTSD な゙の情動記憶が関わる精神疾患 の治療薬としてのグルタミン酸受容体作動薬の有効性について論じた。

2008.1.31 受稿, 2008.4.4 受理 


\section{1. はじめに}

恐怖やストレスと関連した疾患は，我が国において は 1995 年の阪神・淡路大震災や 2001 年の池田小児童 殺傷事件，アメリカにおいては 2001 年 9 月 11 日の同 時多発テロ事件以降，ますます注目されるようになつ た。なかでも特に注目されている疾患は，心的外傷後 ストレス障害 (Posttraumatic Stress Disorder: PTSD) で あり, たつた一度の強度の恐怖体験によって, その後 の生活に多大な影響がみられる。PTSD の症状には, 悪夢, フラッシュバック (再燃現象), 事件の回想に 伴う悪寒，事件の強迫的記憶，回想の回避，集中力の 欠如，過剩反応などが含まれるとされる（American Psychiatric Association, 1994)。またPTSDのひとつの 特徵として, その後の弱いストレッサーや心的外傷的 事象に関連した些細なきっかけに対する過度の反応が 挙げられる。

このPTSD の根底にあると考えられるのが情動記憶 (emotional memory) である。嫌悪事象に関する記憶, いわゆる嫌悪性情動記憶は短期間で形成され，また忘 れにくいことを我々は経験的に知っている。この情動 記憶を完全に消すことができるなら PTSD の治療は容 易であると考えられるが, 上述したように, 情動記憶 は一見消失したように見えて，その後何らかの刺激を きっかけに再燃する特徵をもつ。

情動記憶の消去は, PTSD だけでなく, 不安症の治 療にとっても重要な意味を持つと考えられる。PTSD や不安症の一般的な心理的治療法として, 暴露療法や 系統的脱感作法がよく知られているが, これはまさに 情動記憶の消去であり, 近年多くの研究者たちがこの ような心理的治療をより効果的にするための薬物の開 発に注目している。

また, PTSD と類似した症状をもつ疾患として薬物 依存がある。薬物依存の特徴のひとつに再燃現象があ り, これは薬物の摂取を中止後, 薬物依存の症状が消 失した後でも, 何らかの刺激（薬物の単回摂取やスト レス）をきっかけにその症状が回復する現象である。 このことは，薬物とそれを摃取したときの文脈，ある いは内的状態などの連合記憶が, 恐怖やストレスの記 憶と同様に強固なものであること示す証拠といえ，こ れも一種の情動記憶, すなわち快の情動記憶として扱 うことができると考えられる。

\section{2. ラットにおける情動記憶の測定}

動物を用いた情動記憶の測定法には様々なものがあ るが，ここでは近年よく用いられている測定法のうち， 嫌覀性情動記憶の測定法として恐怖条件づけ, 快の情 動記憶の測定法として条件性場所選好を解説する。

\section{嫌悪性情動記憶の測定：恐怖条件づけ}

情動記憶の獲得の行動的・生物学的メカニズムは古 くからかなり精力的に研究されており，そこでは Pavlov 型恐怖条件づけパラダイムが用いられることが 多い。まず動物, 特にラットに対して光や音といった 最初は中性的な刺激（後に条件刺激：CS となる）を 電気ショック（無条件刺激：US）と対提示すると, その後 CS は条件性恐怖反応（たとえばフリージング） を誘発するようになる。CSによって条件性恐怖反応 がどの程度誘発されるかは, 条件づけ時のUS の強度 に依存し, US の強度が強いほど, 誘発される条件性 恐怖反応は大きい。

また光や音のような刺激だけでなく, ラットはUS が提示された環境のような文脈 (context) とも同時に 連合学習することが知られている。我々の研究室では, 特定の文脈で音 CSに対して恐怖条件づけした後, 異 なる文脈で音 CS を提示し，それに対する恐怖反応を 測定することで, 文脈 CS と切り離して音 CS に対す る情動記憶を測定している。逆に, 条件づけ時に用い た文脈に音 CS なしで再度曝すことによって, 文脈 CS に対する情動記憶を単独で測定することもできる。 Figure 1 は我々の研究室で用いている恐怖条件づけ装 置である。装置 $\mathrm{A}$ は四角いアクリル製の箱であり,

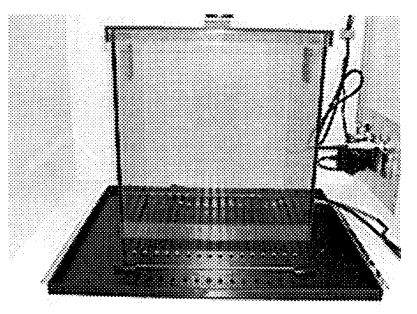

装置 $A$

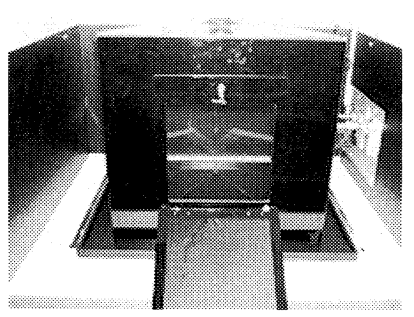

装置 $B$
Figure 1. 古典的恐怖条件づけに用いられる装置。装 置 A の床には足への電撃を与えるためのグリッド があり, 条件づけ時および文脈 CS に対する条件性 恐怖反応のテストに用いられる。装置 B は装置 A と文脈が異なっており，音や光といった手がかり CS に対するテストに用いられる。 
床は足への電気ショックを与えるためのグリッドが並 ベられている。一方, 装置 $\mathrm{B}$ は三角のアクリル製の 箱であり，床も平らなアクリル板でできている。実験 時には，それぞれの装置において異なる照度および背 景音が用いられる。まず装置 A で音や光の CS（手が かりCS）と電気ショックのUS を対提示することで 条件づけを行い，その後それぞれの装置においてフリー ジング反応を測定するテストを行う。条件づけ時と同 じ装置 A でテストを行う場合には, 音や光といった CS を提示せず，装置自体 (文脈 CS) に対する反応を 測定する。一方, 装置 B でテストを行う場合には, 手がかりCS を提示し，それに対する反応を測定できる。 多くの先行研究によって, 手がかりCS に対する条件 づけと文脈に対する条件づけは，異なる脳部位で処理 されていることが示唆されている。手がかりCSに対 する条件づけに関しては扁桃体の関与が，文脈 CSに 対する条件づけに関しては扁桃体および海馬の両方の 関与が有力である。たとえば，扁桃体を破壊すると， 手がかり CS と文脈 CS どちらに対する条件性恐怖反 応も消失するのに対し, 海馬破壊では, 文脈 CS に対 する条件性恐怖反応は消失するが，手がかり CS に対 する反応には影響しない (Phillips \& LeDoux, 1992)。 これら手がかり CS，文脈 CS に対するどちらの条件 性恐怖反応についてもかなり長期間持続することが知 られており (Gale, Anagnostaras, Godsil, Mitchell, Nozawa, Sage, Wiltgen \& Fanselow, 2004), 嫌悪性情動 記憶の動物モデルとして適しているといえる。

さらに恐怖条件づけの前に強いストレス刺激を与え ることで, 後のフリージング反応が強まる現象が知ら れており，これはPTSDの動物モデルの候補として考 えられている。たとえばRau, DeCola \& Fanselow (2005)

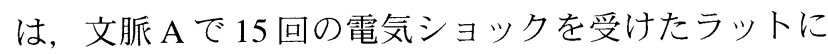
対し，翌日異なる文脈 $\mathrm{B}$ において 1 回だけの電気ショッ クで弱い恐怖条件づけを行い，さらにその翌日，文脈 B でフリージング反応を測定した。その結果, あらか じめ文脈 A で 15 回の電気ショックを受けなかった統 制群に比べて, 15 回の電気ショックというトラウマ 的ストレスを受けた群は, 文脈 Bにおいて, より強 いフリージング反応を示した。

先行する強いストレスによる恐怖条件づけの増強効 果は, Fanselow \& Bolles (1979)の古典的な研究によっ てすでに報告されていた。彼らは通常なら $25 \%$ 程の
フリージング反応しか誘発しない強度の電気ショック が，別の文脈であらかじめより強い電気ショックを与 えておくことにより，80\%のフリージング反応を誘発 することを見いだしている。この増強効果の解釈のひ とつとして, 条件づけにおける般化が考えられる。強 い電気ショックに曝された文脈に対するラットの恐怖 反応が, 同じような特徴をもつ別の文脈に対して般化 しただけなのではないかという考えである。しかしな がら，ある文脈で強い電気ショックに曝された経験の ある動物が，別の新奇な文脈ではフリージング反応 を示さなかったことから (Fanselow, DeCola \& Young, 1993), 先行ストレスの増強効果は単なる般化では説 明できない。さらに興味深いことに, 先行する強い電 気ショックによる条件づけが成立していない状況にお いても，この増強効果はみられる。あらかじめ文脈 $\mathrm{A}$ で 15 回の電気ショックを提示する前に, そこでの条 件づけを阻害する薬物（グルタミン酸 NMDA 受容体 拮抗薬）を投与しても，その後の文脈 B に対する条 件づけは強まることが示されている（Rau et al., 2005）。 これらの知見は, ストレスによる条件づけ増強効果が, 恐怖条件づけにおけるCU-US の連合学習とは独立し たものであることを示唆している。したがって, 先行 する強いストレス経験がその後のストレスに対する感 受性を増強するといえ，これは PTSD 患者でみられる 症状と一致している。

\section{快の情動記憶の測定：条件性場所選好}

条件性場所選好 (conditioned place preference: CPP) は依存性薬物の報酬効果の研究によく用いられる。基 本的には, ラットが薬物を投与された場所をそれ以外 の場所よりもより好むかどうかが問題となる。すなわ ち, 装置の文脈という CS と, 薬物によってもたらさ れる快の状態というUS の間の連合学習と考えられ, これもまた古典的条件づけの一形態といえる。しかし ながら,ここでの条件反応は, 動物が薬物を投与され た場所により長く滞在するという能動的な行動すなわ ちオペラント行動ともいえ, その解釈は複雑である。

一般的に用いられているCPPの装置には, 白と黒

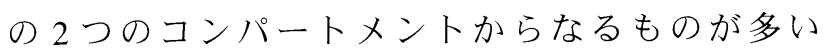
(Figure 2)。ラットは生得的に暗い方を好むので, そ の反対側の白いコンパートメントでの滞在時間が薬物 投与によってどれだけ増加するかがその薬物の報酬特 


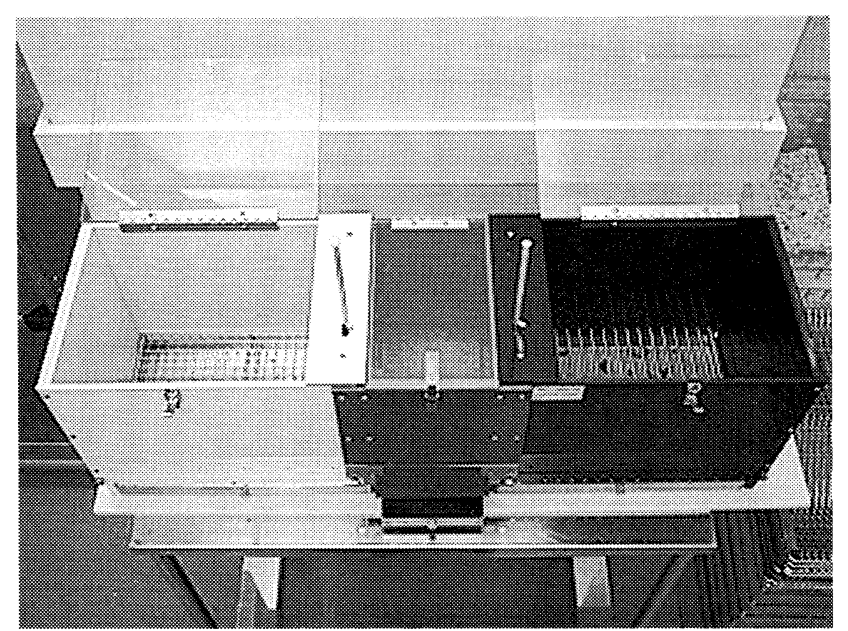

Figure 2. 条件性場所選好テスト装置。ラットは依存 性薬物を投与された直後に, 白色あるいは黒色の いずれかのコンパートメントに一定時間閉じこめ られる（場所条件づけ）ことで，場所に対する選 好を示すようになる。

性の指標とされる。この方法はバイアス法と呼ばれる が，このような元来偏好のあるコンパートメントから 得られたデー夕は薬物の報酬性を正確に反映していな いのではないかという批判もあり，近年では，2つの コンパートメント間の偏好をなくしたノンバイアス法 が用いられる場合も多い。この場合，ラットが好む黒 のコンパートメントに酶酸を塗布したり，照明を明る くしたりすることで条件づけ前のコンパートメント間 の偏好を調節している。

CPPの具体的な方法としては，まず条件づけ試行で

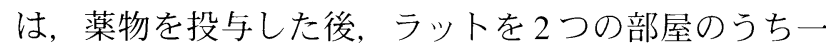
方のコンパートメントに一定時間閉じこめる。その翌 日は薬物を投与しないで他方のコンパートメントに同 時間閉じこめる。これを数回繰り返した後, テスト試 行として，ラットに自由に2つのコンパートメントを 行き来させ，それぞれのコンパートメントに滞在した 時間の合計を測定する。強い依存性を持つことで知ら れているアンフェタミンやコカインなどの薬物で条件 づけされた場合には，ラットは薬物と対提示されたコ ンパートメントに滞在する時間が長くなる。この CPP の手続き上の特徵のひとつとして, テスト試行が薬物 を投与されていない状態で行われる点がある。これは つまり, 実験者が求める薬物の報酬効果を, その薬物 が持つと考えられる他の効果が混入することなく測定 できることを意味する。したがって，テスト試行では
ラットは薬物の報酬効果と文脈との連合記憶に基づい て2つのコンパートメントを選択しているといえ，条 件づけ期に薬物と対提示されたコンパートメントにど れだけ長く滞在するかが快の記憶の指標となる。

また近年, $\mathrm{CPP}$ は薬物の報酬特性の評価だけではな く, 性行動の報酬特性の評価にも用いられている。こ こでは，ラットが性行動を行った直後に2つのコンパー トメントのどちらかに入れられ，性行動に伴う快の状 態と場所とが条件づけられることになる。我々は最近, 雌ラットの性行動によるCPPにおいて, 雌自身のペー スで行われた性行動による条件づけと，相手の雄のペー スで行われた性行動による条件づけでは，異なる神経 メカニズムが関与している可能性を報告した（Yamada, Horibe \& Kondo, 2006)。雌のペースで行われた性行動 による CPP はオピオイド受容体拮抗薬によって阻害 されたが, ドーパミン受容体拮抗薬によっては阻害さ れなかった。一方，雄のペースで行われた性行動によ るCPPについてはその逆の結果が得られた。

\section{3. 情動記憶の消去}

情動記憶の消去は，US を提示しないでCSのみを 提示することで可能となる。たとえば，音 CS と電気 ショックの対提示を受けたラットに対し，その後数回 にわたって音のみを繰り返し提示すると，もはや音 CS はフリージング反応を誘発しなくなる。快の記憶 である CPPについても同様で, 薬物と対提示された コンパートメントに，その後薬物を投与することなく 曝すことで，そのコンパートメントに対する選好は消 失する。

消去の現象自体は, Pavlovによって初期の段階から 示されていたが，この現象は複雑な特性を持っており， その解釈は簡単でない。以下に消去の基本的な行動的 特性について述べる。なお消去という用語には, CS に対する条件性反応を減衰させる実験的手続き自体と, そのような手続きによって反応が減衰する現象のどち らの意味も含まれるが, ここで用いる消去とは後者を 意味することとする。

まず消去はいわゆる忘却ではない。消去過程におい て忘却が起こっている可能性も否定することはできな いが，少なくとも消去が生起するためには単に時間が 経過するだけではなく, US を伴わないCS の単独提 示が必要である。とりわけ条件性恐怖反応に関しては, 
US を伴わないCS の単独提示を行わなければ，月あ るいは年単位というかなりの長期間にわたって保持さ れることが知られている (Gale et al., 2004)。

しかしながら，すでに獲得された条件性反応を消去 する方法は，US をまったく伴わないCS の単独提示 だけというわけでもない。たとえば，CSに随伴する US の頻度が低下しただけでも, 条件性反応は減衰す る（DeVito \& Fowler, 1986）。またUS の強度を最初の 条件づけ時よりも弱めることでも同様の現象がみられ る（Rescorla \& Heth, 1975）。したがって, 消去の生起 においては，CS-US の連合あるいはCS-US の随伴性 を弱めることが重要であるといえる。

また条件づけにおいては般化という現象がよく知ら れているが, 消去はCS に特異的であるといわれている。

Vervliet, Vansteenwegen \& Eelen（2004）は，ヒトを対 象とした恐怖条件づけパラダイムを用いて, 条件づけ の般化がみられるほど類似した刺激間であっても, 消 去の般化はみられないことを報告している。しかしな がら最近我々は，ラットで同時に条件づけられた音 $\mathrm{CS}$ と文脈 CS に関して，一方の CS に対する条件性恐 怖反応の消去が，他方のCSにも般化することを見い だした（原田・山田・新倉・角・一谷, 2007)。我々 のパライダイムでは，音 CS と文脈 CS のどちらもが 条件づけ時に提示されているので，一方のCSに対す る条件づけを行っていない Vervliet et al. (2004) の結 果と直接比較することはできない。消去が般化するの かどうかについては, 臨床的観点からみても重要な問 題であり, 今後詳細な検討が必要とされるだろう。

\section{消去は忘却ではない?}

消去が単なる忘却でない証拠としてよく言及される のが, (1) 自発的回復, (2) 再燃現象, (3) 再学習効果, (4)リニューアル効果の 4 つである。自発的回復は, 消去と同様に Pavlov 自身によって報告された現象で あり, 消去手続きによって一旦減衰した条件反応が, 時間の経過とともに回復することを指す。この場合, 時間経過に依存して回復の程度は大きくなる。自発的 回復は, 条件反応の消去が単なるCS-US 連合の減衰 でなく, 消去後もその連合がほとんど変わらず残って いることを示唆している。

再燃現象もまた, 自発的回復と同様に, 条件反応が 消去後に回復する現象であるが，そこではUS の単独
提示という手がかりが与えられる。再燃現象を最初に 報告した Rescorla \& Heth（1975）は，この現象が消去 されたCSに特異的であり, US の単独提示後少なく とも 24 時間は持続することを見いだした。このことは, 再燃現象が単なる鋭敏化によるものではないことを示 唆している。またその後の研究で, 消去後のUS の単 独提示が, その後に行われるテストと同じ文脈で行わ れなければ再燃現象が見られないこと，USの単独提 示とテストの間にその文脈に対して消去手続きが行わ れると, 恐怖反応の再燃は減弱することが指摘されて いる (Bouton \& Bolles, 1979; Bouton \& King, 1983)。 したがって, 再燃現象には音や光といった手がかり CS に対する条件づけだけでなく，文脈 CS に対する 条件づけにも依存しているといえる。

再学習効果とは, 消去後に再び同じCS とUS を用 いて連合学習をさせた場合, 最初の学習時よりも早く 学習される現象である。その現象もまた, CS-US 連 合が消去後も残存している証拠であると考えられる。

リニューアル効果とは, 消去時と異なる文脈に動物 がおかれたとき，一旦は消去された条件性反応が再び 出現することを意味している。たとえば，ラットが文 脈 A で光 CS に対して恐怖条件づけられるとする。そ の後文脈 $B$ において光 CS に対する消去を行った後, 文脈 $\mathrm{A}, \mathrm{B}$ のいずれかで光 CS に対する反応が測定さ れると, 消去時の文脈 B においてラットは光 CS に対 してほとんどフリージング反応を示さないが, 文脈 $\mathrm{A}$ においてはかなり強いフリージング反応をみせる（Bouton \& Bolles, 1979; Bouton \& King, 1983)。ここまでの結果 の解釈のひとつとして, 光という手がかり CS に対す る消去は行われたが, 装置という文脈 CS に対する消 去は行われていないために, 文脈 CSに対する条件性 反応がみられただけではないかとも考えられる。し かしながらこの可能性は, 条件づけおよび消去時の どちらとも異なる文脈（文脈C）においても条件性恐 怖反応が回復したことから棄却できる（Harris, Jones, Bailey \& Westbrook, 2000)。

\section{新たな学習としての消去}

以上のような現象は, 消去が忘却, すなわち CSUS 連合の減衰として考えると説明ができない。消去 に関して, 現在最も有力な説明は, 消去手続きがCSUS 間の新たな連合学習を促すというものである。た 
だしこの場合の連合は，条件づけ時に形成されたCSUS 連合と拮抗する抑制的な連合である。さらに上述 したリニューアル効果の現象を考慮すると，ラットは ある特定の文脈での CS-no US という抑制的な連合 を学習しているといえる。一般的に, この抑制性の連 合は，条件づけ時に習得されるCS-US の興奮性の連 合よりも脆弱であると考えられており，時間の経過に よって (自発的回復)，あるいは文脈が異なることによっ て（リニューアル効果）弱まる（Bouton, 2004 の総説 を参照)。

\section{4. 情動記憶の消去に関わる脳部位}

情動記憶, とりわけ条件性恐怖反応の消去に関わる 脳部位を特定するための研究は数多くあり, これまで に大脳皮質感覚野（Quirk, Armony, \& LeDoux, 1997; Teich, McCabe, Gentile, Schneiderman, Winters, Liskowsky, \& Schneiderman, 1989), 中脳水道周囲灰白 質 (McNally, Pigg, \& Weidemann, 2004), 下丘 (Heldt $\&$ Falls, 2003), 外側中隔 (Yadin \& Thomas, 1996), 分 界条床核 (Waddell, Morris, \& Bouton, 2006), 線条体 (Josselyn, Falls, Gewirtz, Pistell, \& Davis, 2005; Rogan, Leon, Perez, \& Kandel, 2005）などについての報告があ る。ここではこれまでに最もよく研究されてきた, 扁 桃体, 海馬および前頭前野に関する研究について概観 する。

\section{扁桃体}

大脳辺縁系の一部である扁桃体が情動に関わつてい ることは古くからよく知られている。たとえば, 扁桃 体への電気刺激によって, 怒りや恐怖といった情動を 引き起こし，その損傷は，認知障害だけでなく情動の 変化を生じさせる（Klüver-Bucy 症候群がその代表例 である)。

感覚情報は視床から各関連皮質を経て, 直接あるい は前頭葉を経由して側頭葉へと達し, その後扁桃体に 投射される。ここで感覚情報は統合的に認知され，快・ 不快を含めて評価される。音 CS に対する条件性恐怖 反応に関していえば，単純な音 CS の情報は感覚受容 器, 内側膝状体を経由して直接, 扁桃体の下位区分 である外側核に伝達される。一方, 弁別が要求され るような複雑な音 $\mathrm{CS}$ の情報は, 内側膝状体を経由し た後, 大脳皮質の聴覚野をさらに経由して扁桃体外
側核へ伝達される（Gentile, Jarrell, Teich, McCabe, \& Schneiderman, 1986)。扁桃体外側核からは，直接ある いは基底外側核を経由して中心核へ情報を伝達し,さ らに中心核は，脳幹や春䯣を介して条件性恐怖反応の 表出を調節している（LeDoux, Iwata, Cicchetti, \& Reis, 1988)。

また, 扁桃体外側核や基底外側核は, 条件性恐怖反 応の習得や表出だけでなく, その消去にも重要な役割 を担っていることが報告されている（Sotres-Bayon, Cain, \& LeDoux, 2006; Davis \& Whalen, 2001; Maren, 2001)。ただ扁桃体の損傷は, 条件性恐怖反応の習得 や表出自体に影響を及ぼすことから（LeDoux，2000; LeDoux et al., 1988; Maren, 2001), 消去における扁桃 体の関与を純粋に評価することは難しい。

近年 Akirav, Raizel, \& Maroun（2006）は, 扁桃体基 底外側核を一時的に不活性化することで（抑制性神経 伝達物質 $\gamma$-アミノ酪酸（GABA）の受容体作動薬投 与による), 音 CS に対する条件性恐怖反応の消去が 促進されることを見いだしている。このことは，消去 手続き中の扁桃体基底外側核の活動が，消去に抑制的 な効果をもつことを意味している。しかしながら, 扁 桃体基底外側核の活性化（GABA 受容体拮抗薬投与 による）が文脈 CS に対する消去を促進するという報 告（Berlau \& McGaugh, 2006）もあり, 消去における 扁桃体の詳細な役割についてはまだ議論の余地がある。 さらにBerlau \& McGaugh（2006）は, 右側の基底外 側核の一時的な不活性化は消去を増強するが, 左側の 不活性化はその後の消去になんら影響を及ぼさないこ とを示しており, 消去における扁桃体の関与には左右 差があるのかもしれない。恐怖条件づけの習得に関し ても, 右側の扁桃体のみの関与が示唆されており (Lalumiere \& McGaugh, 2005)，またヒトを対象とした 研究でも, 情動的情報の処理における扁桃体の機能の 左右差の報告がある（Markowitsch, 1998）。

一方, 快の情動記憶の消去における扁桃体の役割は これまでほとんど研究されていないが, 条件性情動反 応と同様に, 依存性薬物による CPP の形成や表出に 関与していることはいくつかの研究で一致している。 たとえば，条件づけ前あるいはテスト前の扁桃体外側 核の損傷は, アンフェタミンによる CPP を阻害する (Hiroi \& White, 1991; Hsu, Schroeder, \& Packard, 2002)。 基底外側核の損傷もまた, コカインによるCPPの形 
成を阻害する（Brown \& Fibiger, 1993）。

消去に関しては, 扁桃体基底外側核へのアセチルコ リン受容体作動薬投与が, アンフェタミンによる CPP の消去を促進する（Schroeder \& Packard, 2004）一方 で, NMDA 受容体拮抗薬の同領域への投与はコカイ ンによるCPP の消去を阻害する (Feltenstein \& See, 2007) という報告がある。

\section{海馬}

海馬もまた扁桃体と同様に大脳辺縁系の一部である。 海馬は古くから記憶の座としてょく知られているが, 上述したように, 恐怖条件づけに関しては, 音のよう な手がかり CS ではなく, 文脈 CS とUS の連合学習に 関わっている (Phillips \& LeDoux, 1992)。一般に, 海 馬は文脈情報を処理しており，そこで形成された文脈 表象が扁桃体へと送られ，US と連合されると考えら れている (Rudy, Huff, \& Matus-Amat, 2004)。

一度消去された条件性恐怖反応が, US の単独提示 によって復活する再燃現象は, 海馬損傷によって阻害 されることが知られている (Wilson, Brooks, \& Bouton, 1995; Frohardt, Guarraci, \& Bouton, 2000)。文脈 CS に 対する条件づけに依存している再燃現象に, 文脈情 報を処理している海馬が関与していることは容易に 予測できることである。再燃現象と同様に, 文脈 CS に対する条件づけが関与していると考えられるリニュー アル効果もまた, 海馬への GABA 受容体作動薬投与 による不活性化によって阻害される（Corcoran, Desmond, Frey, \& Maren, 2005; Corcoran \& Maren, 2001, 2004; Hobin, Ji, \& Maren, 2006 )。

条件性恐怖反応の消去に関しても, 海馬の関与は文 脈CS に限定されているようである。海馬に対する様々 な薬物処置が, 文脈 CS に対する条件づけと考えられ る受動的回避反応の消去に影響を及ぼすことが報告さ れている (Izquierdo \& Medina, 1997)。しかしながら, フリージング反応を指標とした恐怖条件づけの手続き を用いて消去過程における海馬の関与を検討した研究 には, 否定的な見解もあり, 明確な結論は出されてい ない。

\section{内側前頭前野}

情動記憶の消去との関わりにおいて, 近年最も注目 されているのが内側前頭前野である。内側前頭前野は
扁桃体や海馬と相互の神経連絡をもち, 情動記憶の 調節に関与していると考えられている。ヒトの fMRI 研究においては, 条件性恐怖反応の消去過程での前 頭皮質の活動昂進が報告されている（Phelps, Delgado, Nearing, \& LeDoux, 2004)。また PTSD 患者のPET 研 究では, PTSD 症状の生起中の内側前頭皮質の機能不 全が見いだされている（Bremner, Elzinga, Schmahl, \& Vermetten, 2008)。

一般的に, 記憶には基本的な 3 過程, すなわち情報 を入力する記銘過程, 記銘された情報を安定した記憶 として保持する固定（保持）過程, そして保持された 記憶を必要な時に取り出す検索過程があると考えられ ている。このうち固定過程には, 遺伝子発現や蛋白質 合成が必要であることが知られている。たとえば蛋白 質合成阻害薬である anisomycin を恐怖条件づけの直 前に扁桃体基底外側核に局所投与すると, 音 CS に対 する恐怖条件づけは阻害される（Schafe \& LeDoux, 2000; Maren, Ferrario, Corcoran, Desmond, \& Frey, 2003)。 また恐怖条件づけは, 扁桃体基底外側核において最 初期遺伝子 (immediate early genes: IEGs) である c-fos やNGFI-A の発現を促す（Rosen, Fanselow, Young, Sitcoske, \& Maren, 1998; Ressler, Paschall, Zhou, \& Davis, 2002)。

上述したように, 情動記憶の消去では新たな記憶が 形成されているとすると, 消去においても固定過程が あるはずであり，そこには条件づけ習得時と同様に蛋 白質合成や遺伝子発現が関与していると考えられる。 Santini, Muller, \& Quirk（2002）は，消去手続き前に anisomycin を内側前頭前野へ局所投与すると, 消去手 続き中の条件性反応の減衰には影響しないが，一旦消 去された恐怖反応が 24 時間後のテストにおいて回復 することを見いだした。したがって，内側前頭前野は 消去学習の固定に関与していることが示唆される。

ところで, 扁桃体と内側前頭皮質の神経連絡で用い られている主な神経伝達物質としてグルタミン酸があ り, 情動記憶の消去の脳内メカニズムに関する最近の 研究には, 内側前頭前野とグルタミン酸受容体に焦点 を当てたものが多い。そこで次節において, グルタミ ン酸受容体の関与についての研究を概観する。

\section{5. 情動記憶の消去におけるグルタミン酸受容体の関与} グルタミン酸は中枢神経系における興奮性伝達物質 
の一つである。グルタミン酸およびその受容体に関す る詳細は，一谷・吉原・林（2003）において解説され ている。

近年，情動記憶の消去におけるグルタミン酸受容体, とりわけそのサブタイプである N-methyl-D-aspartate （NMDA）受容体の関与を指摘する知見が数多く報告 されている。たとえば，NMDA 受容体拮抗薬を消去 手続きの前に末梢投与（Baker \& Azorlosa，1996; Lee, Milton, \& Everitt, 2006)，あるいは扁桃体基底外側核へ 局所投与 (Lee \& Kim, 1998; Lee et al., 2006; Falls, Miserendino, \& Davis, 1992) すると, フリージング反 応や驚愕反応といつた条件性恐怖反応の消去が阻害 される。Baker \& Azorlosa（1996）では，非競合的 NMDA 受容体拮抗薬である MK-801 $(0.025,0.05,0.1$ $\mathrm{mg} / \mathrm{kg}$ ）が消去手続き前に腹腔内投与された。その結果, MK-801 は用量依存的に条件性恐怖反応の消去を阻害 した。また海馬への NMDA 受容体拮抗薬局所投与によつ ても, 受動的回避反応の消去が阻害されることが報告 されている（Cammarota, Bevilaqua, Barros, Vianna, Izquierdo, Medina, \& Izquierdo, 2005; Szapiro, Vianna, McGaugh, Medina, \& Izquierdo, 2003)。

一方, NMDA 受容体拮抗薬を消去手続きの直前に 腹腔内投与した場合，消去手続き中の消去過程にはまっ たく影響しないが，その 24 時間後のテストにおいて 条件性恐怖反応が回復する（消去が阻害される）とい う報告もある（Santini et al., 2001）。彼らの一連の実 験において，NMDA 受容体拮抗薬の消去手続き前投 与の効果は，その 48 時間後に行われたテストでは消 失している。また消去手続きの直前に NMDA 受容体 拮抗薬を投与し，その 24 時間後に消去手続きを行わ ないで薬物のみを再び投与すると，（消去手続きから） 48 時間後のテストにおいて消去の阻害効果がみられ ている。したがって，消去手続きによって獲得される 新たな情報の記憶（たとえばCS-no US の連合学習）は, その後時間をかけて固定される必要があり, NMDA 受容体拮抗薬はその消去の固定を阻害するのかもしれ ない。しかしながら，より最近になって，海馬やその 近接領域である嗅内皮質に対する NMDA 受容体拮抗 薬の局所投与により，条件恐怖反応の消去が長期間に わたって阻害されるという報告もあり (Szapiro et al., 2003; Bevilaqua, Bonini, Rossato, Izquierdo, Cammarota, \& Izquierdo, 2006), NMDA 受容体が条件性恐怖反応
の消去の記銘・保持・検索のいずれの過程に関与して いるかについてはまだ議論されているところである。

一方, 快の情動記憶の消去における NMDA 受容体 の役割に関する研究はまだ数少ない。しかし最近, Hsu \& Packard（2008）は，アンフェタミンによる CPP の消去に対する競合的 NMDA 受容体拮抗薬の内 側前頭前野投与の効果を検証し，NMDA 受容体拮抗 薬が CPP の消去を阻害することを明らかにしている。 したがって, 快の情動記憶の消去においても, 嫌悪性 情動記憶と同様のメカニズムの存在が考えられ, 今後 の研究が期待される。

さて，NMDA 受容体を遮断すると情動記憶の消去 が阻害されるならば，では逆にNMDA 受容体を活性 化するとその消去は促進されるのだろうか。PTSD ゃ 不安症, 薬物依存の治療にとつて有益であるのは, 抑 制効果よりも，いかに情動記憶を早く消去できるかと いう促進効果のほうである。

NMDA 受容体を活性化することにより，情動記憶 の消去が促進されることを最初に報告したのは Walker, Ressler, Lu, \& Davis（2002）である。彼らは消 去手続き前の部分的 NMDA 受容体作動薬 Dcycloserine（DCS）投与が，末梢投与および扁桃体へ の局所投与のいずれであっても，条件性恐怖反応の消 去を促進することを見いだした。DCS は NMDA 受容 体の構成部位のひとつであるグリシン調節部位に作用 し，NMDA 受容体の活性を上げる。彼らは，ラット に光 CS と電気ショックUS との対提示を 10 回行うこ とで条件づけをした 48 時間後, 30 回の CS の単独提 示により消去を行つた。この消去手続きの 30 分前に, DCS あるいは生理食塩水を腹腔内投与し，その翌日 にCS に対する恐怖反応を観察した。ここでの恐怖反 応の指標は，音に対する驚愕反応が用いられ，CS が 恐怖を誘発するならば，CSが提示された時のほうが, 提示されない時よりも音に対する驚愕反応は大きくな ると考えられた。その結果，DCS を消去前に投与さ れたラットは, 生理食塩水を投与された統制群より CS に対する恐怖反応が小さかった。このDCS の効果 は，消去手続きを行われたラットのみにみられ，よっ て DCS の非特異的な効果によるものではないといえる。 さらに, DCS の効果は用量依存的であり，15 あるい は $30 \mathrm{mg} / \mathrm{kg}$ の用量では消去の促進効果が認められたが, $3.25 \mathrm{mg} / \mathrm{kg}$ ではその効果はみられなかった。 
その後, フリージング反応に関しても, Ledgerwood, Richardson, \& Cranney（2003）が DCS の消去促進効果 を報告している。彼らの研究では, 光 CS と電気ショッ クUS の対提示を 5 回行うことで条件づけをした翌日に, 6 回の CS の単独提示により消去を行っている。半数 のラットは消去手続きの直後にDCS を, 残りの半数 は生理食塩水を腹腔内投与された。また別のラットに は，消去手続きを行わないで，DCS あるいは生理食 塩水のいずれかが投与された。その後 CS に対するフリー ジング反応を群間で比較したところ，消去後にDCS を投与された群は, 他の 3 群に比べてフリージング反 応が減弱していた。さらに彼らは，DCS の消去手続 き前の投与についても検討しており，消去前投与によつ ても促進効果がみられるが，その効果は消去後投与よ りも弱いこと, また消去後投与の効果は消去から薬物 投与までの間隔の長さに依存して減弱していくことか ら，DCS の効果は消去学習の固定を調節しているの ではないかと推察している。このことは, 上述した NMDA 拮抗薬の効果に関するいくつかの研究と一致 する。

より最近では, Lee et al.（2006）はDCSの扁桃体 基底外側核投与が音 CS に対するフリージング反応の 消去を促進することを報告している。彼らの研究では 消去手続き前の投与の効果しか検討されていないので, 固定過程におけるNMDA 受容体の関与について言及 することはできないが, いずれにせよ扁桃体, 海馬, そして内側前頭前野の NMDA 受容体が情動記憶の消 去に関与していることは明白である。

これまで非 NMDAグルタミン酸受容体の関与につ いてはまだ十分に検討されていないが, AMPA/kainate 受容体の拮抗薬である 6-cyano-7-nitroquinoxaline-2,3dione（CNQX）の消去前投与は，その後の消去に対 して影響しないことが報告されている（Falls et al., 1992; Lin, Yeh, Lu, \& Gean, 2003)。一方で, 代謝型グ ルタミン酸受容体（mGluR）が条件性恐怖反応の消去 に関与していることを示す証拠が最近報告された (Callaerts-Vegh, Beckers, Ball, Baeyens, Callaerts, Cryan, Molnar, \& D'Hooge, 2006)。mGluRのサブタイプのひ とつ mGluR7 が扁桃体のプレシナプスに多く存在し, グルタミン酸の放出を抑制していると考えられている ことから, 扁桃体を介した消去の調節が示唆される。

\section{6. まとめ}

ここまで情動記憶の消去に関与している脳内メカニ ズムの一部について研究を概観してきた。情動記憶の 獲得における扁桃体や海馬の関与を示すデー夕はかな り蓄積されており, それらの部位は消去にも深い関わ りをもつ。また情動記憶の消去の調節に関しては内側 前頭前野も主要な役割を担っていると考えられる。さ らにPTSD や不安症の薬理学的な治療法の開発にむけ て, 現在 NMDA 受容体を中心とした研究がさかんに 行われている。とくに他のNMDA 受容体作動薬に比 ベて神経毒性が少ない DCS の臨床的応用が期待され ている。今後は薬物依存の治療を視野に入れ, 快の情 動記憶の消去を含めたメカニズムの解明が必要であろ う。

ところで上述したように，ヒトや動物の記憶過程に おいて新たに記銘された情報は, その直後の固定過程 を経て, 長期記憶として安定した状態になると考えら れてきた。しかし Nader, Schafe, \& LeDoux (2000) は, 一度固定された記憶でもそれが再活性された時に不安 定になり，再び固定されることを報告している（記憶 の再固定仮説)。この再固定仮説にしたがうと, ラッ トの恐怖条件づけにおいて, CSの単独提示は, すで に獲得された情動記憶の再固定を導くことになる。

しかしながらその一方で, CS の単独提示は情動記 憶の消去を引き起こす。CSの単独提示によって記憶 の再固定が生じるのか, あるいは消去が生じるのかは 単独提示の程度に依存し, 弱い（時間が短い, 回数が 少ない）と再固定が，強くなると消去が生じると考え られている。

このことに関連して近年, Lee et al. (2006) は, NMDA 受容体拮抗薬 MK-801 とその作動薬の DCS の 効果が, CS の単独提示の程度に依存することを見い だした。CSの単独提示が 60 秒の場合（再固定が起こ るとされる条件）には，MK-801の末梢投与がその後 の条件性恐怖反応を減弱させたが, 単独提示が 600 秒 の場合（消去が起こるとされる条件）ではその効果は みられず，条件性恐怖反応は維持された。したがって， NMDA 受容体遮断によって, 記憶の再固定および消 去のどちらもが阻害されたといえる。一方 DCS の末 梢投与および扁桃体基底外側核への局所投与は, CS の単独提示が短い場合には条件性恐怖反応を増強した が, 単独提示が長い場合には逆に減弱した。したがつ 
て，NMDA 受容体活性化によって，記憶の再固定お よび消去のどちらもが促進されたといえる。これらの 知見は, PTSDの治療において暴露療法と薬物療法を 併用する場合, トラウマ記憶に対する暴露の程度と薬 物の効果の方向性を十分に見極める必要性を示唆して いる。

\section{引用文献}

Akirav, I., Raizel, H., \& Maroun, M. (2006). Enhancement of conditioned fear extinction by infusion of the $\mathrm{GABA}_{\mathrm{A}}$ agonist muscimol into the rat prefrontal cortex and amygdala. European Journal of Neuroscience, 23, 758764.

American Psychiatric Association (1994). Quick reference to the Diagnostic Criteria from DSM- IV . 高橋三郎 - 大 野裕・染矢俊幸（訳）DSM- IV 精神疾患の分類と診 断の手引き医学書院

Baker, J. D., \& Azorlosa, J. L. (1996). The NMDA antagonist MK-801 blocks the extinction of Pavlovian fear conditioning. Behavioral Neuroscience, 110, 618620.

Berlau, D. J., \& McGaugh, J. L. (2006). Enhancement of extinction memory consolidation: the role of the noradrenergic and GABAergic systems within the basolateral amygdala. Neurobiology of Learning \& Memory, 86, 123-132.

Bevilaqua, L. R., Bonini, J. S., Rossato, J. I., Izquierdo, L. A., Cammarota, M., \& Izquierdo, I. (2006). The entorhinal cortex plays a role in extinction. Neurobiology of Learning \& Memory, 85, 192-197.

Bouton, M. E. (2004). Context and behavioral processes in extinction. Learning \& Memory, 11, 485-494.

Bouton, M. E., \& Bolles, R. C. (1979). Role of conditioned contextual stimuli in reinstatement of extinguished fear. Journal of Experimental Psychology: Animal Behavior Processes, 5, 368-378.

Bouton, M. E., \& King, D. A. (1983). Contexual control of conditioned fear: tests for the associateve value of the contex. Journal of Experimental Psychology: Animal Behavior Processes, 9, 248-256.

Bremner, J. D. , Elzinga, B., Schmahl, C., \& Vermetten, E. (2008). Structual and functional plasticity of the human brain in posttraumatic stress disorder. Progress in Brain Research, 167, 171-186.

Brown, E. E., \& Fibiger, H. C. (1993). Differential effects of excitotoxic lesions of the amygdala on cocaineinduced conditioned locomotion and conditioned place preference. Psychopharmacology, 113, 123-130.

Callaerts-Vegh, Z., Beckers, T., Ball, S. M., Baeyens, F., Callaerts, P. F., Cryan, J. F. Molnar, E., \& D'Hooge, R. (2006). Concomitant deficits in working memory and fear extinction are functionally dissociated from reduced anxiety in metabotropic glutamate receptor 7-deficient mice. Journal of Neuroscience, 26, 6573-6582.

Cammarota, M., Bevilaqua, L. R., Barros, D. M., Vianna, M. R., Izquierdo, L. A., Medina, J. H., \& Izquierdo, I. (2005). Retrieval and the extinction of memory. Cellular and Molecular Neurobiology, 25, 465-474.

Corcoran, K. A., Desmond, T. J., Frey, K. A., \& Maren, S. (2005). Hippocampal inactivation disrupts the acquisition and contextual encoding of fear extinction. Journal of Neuroscience, 25, 8978-8987.

Corcoran, K. A., \& Maren, S. (2001). Hippocampal inactivation disrupts contextual retrieval of fear memory after extinction. Journal of Neuroscience, 21, 1720-1726.

Corcoran, K. A., \& Maren, S. (2004). Factors regulating the effects of hippocampal inactivation on renewal of conditional fear after extinction. Learning \& Memory, 11, 598-603.

Davis, M., \& Whalen, P. J. (2001). The amygdala: vigilance and emotion. Molecular Psychiatry, 6, 13-34.

DeVito, P. L., \& Fowler, H. (1986). Effects of contingency violations on the extinction of a conditioned fear inhibitor and a conditioned fear excitor. Journal of Experimental Psychology: Animal Behavior Processes, 12, 99-115.

Falls, W. A., Miserendino, M. J., \& Davis, M. (1992). Extinction of fear-potentiated startle: blockade by infusion of an NMDA antagonist into the amygdala. Journal of Neuroscience, 12, 854-863.

Fanselow, M. S., \& Bolles, R. C. (1979). Naloxone and shock-elicited freezing in the rat. Journal of Comparative and Physiological Psychology, 93, 736-744.

Fanselow, M. S., DeCola, J. P., \& Young, S. L. (1993). 
Mechanisms responsible for reduced contextual conditioning with massed unsignaled unconditional stimuli. Journal of Experimental Psychology: Animal Behavior Processes, 19, 121-137.

Feltenstein, M. W., \& See, R. E. (2007). NMDA receptor blockade in the basolateral amygdala disrupts consolidation of stimulus-reward memory and extinction learning during reinstatement of cocain-seeking in an animal model of relapse. Neurobiology of Learning \& Memory, 88, 435-444.

Frohardt, R. J., Guarraci, F. A., \& Bouton, M. E. (2000). The effects of neurotoxic hippocampal lesions on two effects of context after fear extinction. Behavioral Neuroscience, 114, 227-240.

Gale, G. D., Anagnostaras, S. G., Godsil, B. P., Mitchell, S., Nozawa, T., Sage, J. R., Wiltgen, B., \& Fanselow, M. S. (2004). Role of the basolateral amygdala in the storage of fear memories across the adult lifetime of rats. Journal of Neuroscience, 24, 3810-3815.

Gentile, C. G., Jarrell, T. W., Teich, A., McCabe, P. M., \& Schneiderman, N. (1986). The role of amygdaloid central nucleus in the retention of differential pavlovian conditioning of bradycardia in rabbits. Behavioral Brain Research, 20, 263-273.

原田和保 - 山田一夫 · 新倉怜 - 角正美 - 一谷幸男 (2007). ラットの恐怖条件づけの消去学習の固定に 及ぼすNMDA 受容体拮抗薬の効果 日本動物心理 学会第 67 回大会.

Harris, J. A., Jones, M. L., Bailey, G. K., \& Westbrook, R. F. (2000). Contextual control over conditioned responding in an extinction paradigm. Journal of Experimental Psychology: Animal Behavior Processes, 26, 174-185.

Heldt, S. A., \& Falls, W. A. (2003). Destruction of the inferior colliculus disrupts the production and inhibition of fear conditioned to an acoustic stimulus. Behavioral Brain Research, 144, 175-185.

Hiroi, N., \& White, N. M. (1991). The lateral nucleus of the amygdala mediates expression of the amphetamineproduced conditioned place preference. Journal of Neuroscience, 11, 2107-2116.

Hobin, J. A., Ji, J., \& Maren, S. (2006). Ventral hippocampal muscimol disrupts context-specific fear memory retrieval after extinction in rats. Hippocampus, 16, 174-182.

Hsu, E., \& Packard, M. G. (2008). Medial prefrontal cortex infusions of bupivacaine or AP-5 block extinction of amphetamine conditioned place preference. Neurobiolology of Learning \& Memory, 89, 504-512

Hsu, E. H., Schroeder, J. P., \& Packard, M. G. (2002). The amygdala mediates memory consolidation for an amphetamine conditioned place preference. Behavioral Brain Research, 129, 93-100.

一谷幸男・吉原亨・林和子 (2003). ラット・マウスの 空間認知・空間記憶における脳内グルタミン酸受容 体の役割 生理心理学と精神生理学, 21, 5-17.

Izquierdo, I., \& Medina, J. H. (1997). Memory formation: the sequence of biochemical events in the hippocampus and its connection to activity in other brain structures. Neurobiology of Learning \& Memory, 68, 285-316.

Josselyn, S. A., Falls, W. A., Gewirtz, J. C., Pistell, P., \& Davis, M. (2005). The nucleus accumbens is not critically involved in mediating the effects of a safety signal on behavior. Neuropsychopharmacology, 30, 1726.

Lalumiere, R. T., \& McGaugh, J. L. (2005). Memory enhancement induced by post-training intrabasolateral amygdala infusions of beta-adrenergic or muscarinic agonists requires activation of dopamine receptors: Involvement of right, but not left, basolateral amygdala. Learning \& Memory, 12, 527-532.

Ledgerwood, L., Richardson, R., \& Cranney, J. (2003). Effects of D-cycloserine on extinction of conditioned freezing. Behavioral Neuroscience, 117, 341-349.

LeDoux, J. E. (2000). Emotion circuits in the brain. Annual Review of Neuroscience, 23, 155-184.

LeDoux, J. E., Iwata, J., Cicchetti, P., \& Reis, D. J. (1988). Different projections of the central amygdaloid nucleus mediate autonomic and behavioral correlates of conditioned fear. Journal of Neuroscience, 8, 2517-2529.

Lee, H., \& Kim, J. J. (1998). Amygdalar NMDA receptors are critical for new fear learning in previously fearconditioned rats. Journal of Neuroscience, 18, 84448454. 
Lee, J. L., Milton, A. L., \& Everitt, B. J. (2006). Reconsolidation and extinction of conditioned fear: inhibition and potentiation. Journal of Neuroscience, 26, 10051-10056.

Lin, C. H., Yeh, S. H., Lu, H. Y., \& Gean, P. W. (2003). The similarities and diversities of signal pathways leading to consolidation of conditioning and consolidation of extinction of fear memory. Journal of Neuroscience, 23, 8310-8317.

Maren, S. (2001). Is there savings for pavlovian fear conditioning after neurotoxic basolateral amygdala lesions in rats? Neurobiology of Learning \& Memory, 76, 268-283.

Maren, S., Ferrario, C. R., Corcoran, K. A., Desmond, T. J., $\&$ Frey, K. A. (2003). Protein synthesis in the amygdala, but not the auditory thalamus, is required for consolidation of Pavlovian fear conditioning in rats. European Journal of Neuroscience, 18, 3080-3088.

Markowitsch, H. J. (1998). Differential contribution of right and left amygdala to affective information processing. Behavioural Neurology, 11, 233-244.

McNally, G. P., Pigg, M., \& Weidemann, G. (2004). Opioid receptors in the midbrain periaqueductal gray regulate extinction of pavlovian fear conditioning. Journal of Neuroscience, 24, 6912-6919.

Nader, K., Schafe, G. E., \& LeDoux, J. E. (2000). Fear memories require protein synthesis in the amygdala for reconsolidation after retrieval. Nature, 406, 722-726.

Phelps, E. A., Delgado, M. R., Nearing, K. I., \& LeDoux, J. E. (2004). Extinction learning in humans: role of the amygdala and vmPFC. Neuron, 43, 897-905.

Phillips, R. G., \& LeDoux, J. E. (1992). Differential contribution of amygdala and hippocampus to cued and contextual fear conditioning. Behavioral Neuroscience, 106, 274-285.

Quirk, G. J., Armony, J. L., \& LeDoux, J. E. (1997). Fear conditioning enhances different temporal components of tone-evoked spike trains in auditory cortex and lateral amygdala. Neuron, 19, 613-624.

Rau, V., DeCola, J. P., \& Fanselow, M. S. (2005). Stressinduced enhancement of fear learning: an animal model of posttraumatic stress disorder. Neuroscience and
Biobehavioral Reviews, 29, 1207-1223.

Rescorla, R. A., \& Heth, C. D. (1975). Reinstatement of fear to an extinguished conditioned stimulus. Journal of Experimental Psychology: Animal Behavior Processes, 1, 88-96.

Ressler, K. J., Paschall, G., Zhou, X. L., \& Davis, M. (2002). Regulation of synaptic plasticity genes during consolidation of fear conditioning. Journal of Neuroscience, 22, 7892-7902.

Rogan, M. T., Leon, K. S., Perez, D. L., \& Kandel, E. R. (2005). Distinct neural signatures for safety and danger in the amygdala and striatum of the mouse. Neuron, $\mathbf{4 6}$, 309-320.

Rosen, J. B., Fanselow, M. S., Young, S. L., Sitcoske, M., \& Maren, S. (1998). Immediate-early gene expression in the amygdala following footshock stress and contextual fear conditioning. Brain Research, 796, 132-142.

Rudy, J. W., Huff, N. C., \& Matus-Amat, P. (2004). Understanding contextual fear conditioning: insights from a two-process model. Neuroscience and Biobehavioral Reviews, 28, 675-685.

Santini, E., Muller, R. U., \& Quirk, G. J. (2001). Consolidation of extinction learning involves transfer from NMDA-independent to NMDA-dependent memory. Journal of Neuroscience, 21, 9009-9017.

Schafe, G. E., \& LeDoux, J. E. (2000). Memory consolidation of auditory pavlovian fear conditioning requires protein synthesis and protein kinase $\mathrm{A}$ in the amygdala. Journal of Neuroscience, 20, RC96.

Schroeder, J. P., \& Packard, M. G. (2004). Facilitation of memory for extinction of drug-induced conditioned reward: role of amygdala and acetylcholine. Learning \& Memory, 11, 641-647.

Sotres-Bayon, F., Cain, C. K., \& LeDoux, J. E. (2006). Brain mechanisms of fear extinction: historical perspectives on the contribution of prefrontal cortex. Biological Psychiatry, 60, 329-336.

Szapiro, G., Vianna, M. R., McGaugh, J. L., Medina, J. H., \& Izquierdo, I. (2003). The role of NMDA glutamate receptors, PKA, MAPK, and CAMKII in the hippocampus in extinction of conditioned fear. Hippocampus, 13, 53-58. 
Teich, A. H., McCabe, P. M., Gentile, C. C., Schneiderman, L. S., Winters, R. W., Liskowsky, D. R., \& Schneiderman, N. (1989). Auditory cortex lesions prevent the extinction of Pavlovian differential heart rate conditioning to tonal stimuli in rabbits. Brain Research, 480, 210-218.

Vervliet, B., Vansteenwegen, D., \& Eelen, P. (2004). Generalization of extinguished skin conductance responding in human fear conditioning. Learning \& Memory, 11, 555-558.

Waddell, J., Morris, R. W., \& Bouton, M. E. (2006). Effects of bed nucleus of the stria terminalis lesions on conditioned anxiety: aversive conditioning with longduration conditional stimuli and reinstatement of extinguished fear. Behavioral Neuroscience, 120, 324336.
Walker, D. L., Ressler, K. J., Lu, K. T., \& Davis, M. (2002). Facilitation of conditioned fear extinction by systemic administration or intra-amygdala infusions of Dcycloserine as assessed with fear-potentiated startle in rats. Journal of Neuroscience, 22, 2343-2351.

Wilson, A., Brooks, D. C., \& Bouton, M. E. (1995). The role of the rat hippocampal system in several effects of context in extinction. Behavioral Neuroscience, 109, 828-836.

Yadin, E., \& Thomas, E. (1996). Stimulation of the lateral septum attenuates immobilization-induced stress ulcers. Physiology \& Behavior, 59, 883-886.

Yamada, K., Horibe, S., \& Kondo, Y. (2006). Effects of opiate antagonist on mating-induced conditioned place preference in female rats. Society for Behavioral Neuroendocrinology, 10th Annual Meeting. 